JURNAL PENDIDIKAN, p-ISSN 2715-095X, e-ISSN 2686-5041

Volume 30, No.1, Maret 2021 (133-142)

Online: http://journal.univetbantara.ac.id/index.php/jp

\title{
Peningkatan Prestasi Belajar IPS Materi Aktivitas Ekonomi Melalui Model Team AssistedIndividualization SD Negeri Bendosari 03 Semester 2 Tahun Pelajaran 2018/2019
}

\author{
Resmiyati \\ Guru Kelas SD Negeri Bendosari 03 Sukoharjo, email: resmiyatispd@gmail.com
}

\begin{abstract}
Abstrak: Penelitian ini dilatarbelakangi rendahnya prestasi pembelajaran IPS pada siswa kelas IV SD Negeri Bendosari 03 Kecamatan Bendosari Kabupaten Sukoharjo. Dari 8 siswa kelas IV hanya 4 orang yang tuntas dalam mengerjakan tes pada kondisi awal dengan nilai tertinggi 80 dan nilai terendah 50, dengan rata rata nilai 66 . Penelitian ini bertujuan untuk mengetahui sejauh mana keberhasilan prestasi belajar IPS pada materi aktivitas ekonomi siswa Kelas IV SD Negeri Bendosari 03, Kecamatan Bendosari, Kabupaten Sukoharjo, Semester 2 Tahun Pelajaran 2018/2019 melalui penggunakan model pembelajaran Team AssistedIndividualization.Pelaksanaan dilaksanakan melalui tahapan dua siklus, Pelaksanaan Tindakan Kelas ini dilakukan di SD Negeri Bendosari 03 Kecamatan Bendosari Kabupaten Sukoharjo pada siswa kelas IV semester 2. Waktu penelitian selama 5 bulan yaitu dari Januari 2019 sampai dengan Mei 2019. Kegiatan tersebut dibagi dalam tahapan yaitu perencanaan, pelaksanaan, observasi dan refleksi. Sumber data penelitian berupa hasil tes siswa kondisi awal, siklus I dan siklus II. Hasil penelitian menyatakan bahwa melalui modelTeam AssistedIndividualization, prestasi belajar IPSMateri Aktivitas Ekonomi Siswa Kelas IV SD Negeri Bendosari 03 Kecamatan Bendosari Kabupaten Sukoharjo Semester 2, Tahun Pelajaran 2018/2019, terbukti dapat meningkatkan" .
\end{abstract}

Kata-kata Kunci: Team AssistedIndividualization, pembelajaran, IPS

\section{Improved Social Studies Learning Material for Economic Activities Through the Team Assisted Individualization Model SD Negeri Bendosari 03 Semester 2 Academic Year 2018/2019}

\author{
Resmiyati
}

The teacher of SD Negeri Bendosari 03 Sukoharjo,email: resmiyatispd@gmail.com

\begin{abstract}
Sukoharjo Regency, Semester 2 of the 2018/2019 academic year. ; through the use of the Team Assisted Individualization learning model. The implementation was carried out through two cycles of stages, the implementation of this Class Action was carried out at SD Negeri Bendosari 03, Bendosari District, Sukoharjo Regency in grade IV students in semester 2 of the 2018/2019 academic year. stages, namely planning, implementation, observation and reflection. Sources of research data in the form of student test results in the initial conditions, cycle I and cycle II. The results showed that "Through the Team Assisted Individualization Model the social studies learning achievement of the Economic Activity Material of Class IV SD Negeri Bendosari 03 Bendosari District, Sukoharjo Regency Semester 2, Academic Year 2018/2019, is proven to improve
\end{abstract}


Keywords: Team Assisted Individualization, Learning, Social Studies

\section{Pendahuluan}

Ilmu Pengetahuan Sosial atau biasa disingkat dengan IPStingkat SD perkembangannya mempunyai peningkatan yang pesat. Baik dari isi materinya juga dari cara penyampaiannya. Pembelajaran IPS yang diperuntukkan bagi siswa kelas tinggi atau kelas IV s/d VI sudah berisi tentang pemahaman logika. Bukan hanya pengetahuan di lingkungan sekitar saja namun sudah merambah kepada kegiatan dunia. Baik di bidang politik, ekonomi, sosial maupun budaya. Pelajaran IPS, merupakan salah satu ilmu yang mengedaepankan tentang pemikirian dan mengingat. Siswa ketika sudah mendengar pelajaran IPS maka yang diingat hanyalah pelajaran hapalan. Sayangnya IPS di sekolah dasar terutama di kelas tinggi atau kelas IV sampai dengan kelas VI sangat dipengaruhi oleh kemampuan guru dalam penyampaian materi. Proses pembelajaran juga sangat dipengaruhi oleh kemampuan guru dalam pemilihan metode, model dan strategi pembelajaran. Model pembelajaran merupakan pola yang digunakan guru untuk mempresentasikan pembelajaran agar tujuan pembelajaran tercapai (Trianto, 2011: 23). Oleh karena itu yang perlu di perhatikan adalah ketepatan dalam memilih model mengajar harus sesuai dengan tujuan, jenis dan sifat materi yang diajarkan.

Model pembelajaran yang diterapkan oleh guru saat ini cenderung masih menggunakan cara tradisional. Pembelajaran sekarang ini masih banyak ditemukan guru memakai model ceramah dimana fokus seluruh pelajaran ada pada guru. Interaksi dalam kelas cenderung tergolong masih rendah, siswa cenderung hanya mendengarkan dan mencatat, tidak ada tanya jawab untuk penguatan materi dari guru.Hal tersebut seperti yang terjadi pada siswa kelas IV SDN Bendosari 03 Kecamatan Bendosari Kabupaten Sukoharjo. Pembelajaran IPS sangat rendah. Siswa kelas IV, SDN Bendosari 03 berjumlah 8 siswa, hanya 4 orang yang tuntas dalam mengerjakan tes pada kondisi awal. Dengan nilai tertinggi 80 dan nilai terendah 50, dengan rata rata nilai 66. Dari sini dapat dilihat bahwa ada kesalahan dalam pembelajaran Ilmu Pengetahuan Sosial. Setelah ditelusuri, ternyata pembelajaran ceramah selama ini terbukti kurang mampu dipahami oleh siswa. Siswa hanya menangkap sebagian kecil saja materi yang diberikan. Penulis akan mencoba melakukan perubahan dalam pembelajaran yaitu menggunakan model Team AssistedIndividualization. Belajar didefinisikan sebagai tahapan manusia untuk mencapai berbagai macam kompetensi, keterampilan dan sikap. Karakteristik penting yang membedakan manusia dengan makhluk hidup lainnya adalah kemampuan manusia untuk belajar. (Dimyati, 2002 : 10). Belajar merupakan suatu tahap upaya yang dilakukan untuk mencapai suatu perubahan sikap yang baru, secara keseluruhan, sebagai hasil pengalamannya dalam interaksi dengan lingkungannya (Slameto 2003:2)Berdasarkan dua pendapat di atas, dapat disimpulkan bahwa pembelajaran adalah kegiatan interaksi dalam rangka mengubah tingkah laku dalam suatu lingkungan. Prestasi belajar merupakan hasil yang diperoleh seseorang dalam pengusasaan ilmu pengetahuan dan keterampilan yang terkembang dalam suatu pelajaran, seperti halnya ditunjukkan dengan tes angka nilai yang diberikan oleh guru (Asmara, 2009: 89). Prestasi belajar merupakan kecakapan yang ditampilkandalam kumpulan pengetahuan (Hetika, 2008: 45). Prestasi merupakan sebuah hasil upaya yang dilaksanakan untuk mencapai perubahan yang dinyatakan dalam bentuk pola untuk menampakkan kemampuan pencapaian dalam hasil peketjaan dalam waktu tertentu (Harjati, 2008: 93). Prestasi belajar siswa dapat terpengaruh oleh beberapa hal, baik dari factor internal ataupun factor eksternal siswa tersebut. Pada hakikatnya prestasi belajar merupakan capaian siswa dalam hal mata pelajaran yang mampu mnegubah 
karakter siswa, pengetahuan siswa tentang suatu hal dan perubah perilaku siswa ke arah positif, dan dibuktikan dalam suatu hasil yang nyata. Ilmu Pengetahuan Sosial merupakan salah satu pelajaran inti yang diajarkan pada siswa SD meliputi ekonomi, sosiologi, tata negara, antropologi, geografi, sejarah dan ilmu yang mempelajari kehidupan sosial lainnya termasuk dalam muatan pelajaran IPS. Pembelajaran IPS SD berfungsi agar siswa mampu mengembangkan diri dalam masyarakat Indonesia dan masyarakat dunia, baik masa lampau, masa sekarang dan masa yang akan datang. IPS dinyatakan sebagai salah satu cabang ilmu bertujuan untuk membekali siswa agar bisa berkembang penalarannya melalui aspek nilai, moral dan sosial sehingga dapat menambah bekal pengetahuan dan informasi (Winataputra,dkk, 2005:9.3). Pembelajaran IPS pada tingkat sekolah dasar merupakan salah satu usaha untuk membekali siswa mengenai konsep yang berkaitan dengan ilmu social yang dikembangkan secara terpadu dan disesuaikan perkembangan usia pada masa sekolah dasar (Aat, 2016:50). Sikap yang harus dikembangkan oleh siswa antara lain: (1) Sikap ingin tahu(Curiosity), rasa keiingin tahuan ditandai dengan tingginya minat siswa terhadap perilaku alam sekitarnya. Anak selalu mengamati benda-benda disekitarnya, melakukan pencarian informasi yang lebih pada benda yang ditemukanya dan melakukan pengalamanbaru. (2) Sikap luwes mengenai gagasan baru (flexibility), sikap ini membangun konsep anak untuk mendalami lingkungannya yang sejalan seiring penambahan pengalaman baru.(3) Sikap merenung dengan kritis (critical reflection) harus mulai dibiasakan kaitannya dalam belajar Ilmu Pengetahuan Sosial, anak terbiasa merenung, mengulang lagi kegiatan yang telah terlaksana, dalam penerapannya di kehidupan diterapkan melalui saran kritis terhadap dirinya sendiri.

Model pembelajaran Tipe Team Assisted Individualizationtermasuk model pembelajaran kooperatif. Semua model pembelajaran kooperatif ditandai dengan adanya struktur tugas, struktur tujuan dan struktur penghargaan. Pada kegiatan belajar dengan model ini mendorong siswa saling bekerjasama untuk menyelesaia tugas, mereka harus bersama sama berkoordinasi agar dapat menyelesaikan tugasnya. Tujuan dari model ini adalah meningkatnya prestasi belajar akademik sehingga siswa mampu menerima keragaman dari temannya, juga pengembangan keterampilan sosial. Model Team Assisted Individualization ini dikembangkan oleh Slavin. Slavin (2005: 143) menyatakan model ini memadukankelebihandari pembelajaran kelompok dan pembelajaran individual. Menurut Ni Luh Sutiari (2019: 34) TAI (Team Assisted Individualization) merupakan model pembelajaran yang memfasilitasi siswa dengan kelompok kecil yang masing-masing dengan kemampuan yang berbeda untuk mengasah kemampuan individunya. Tipe ini dikembangkan untuk mengatasi kesulitan belajar individual siswa. Oleh karena itu, kegiatannya lebih dominan digunakan dalam pemecahan masalah, ciri khusus pada model Tipe Team Assisted Individualization ini adalah tiap siswa secara individu mempelajari materi belajar yang telah di berikan oleh guru. Implementasi model tipe Team Assisted Individualization dalam pembelajaran dapat memudahkan pemahaman materisiswaa karena siswa mampu mengekspolrasi pengetahuannya sendiri, serta antusias sepanjang pembelajaran sehingga mampu mengatasi masalah. Hal ini seperti yang disampaikan oleh I Gusti Agung Inten Prabaningrum dalam penelitiannya yang menggunakan model yang sama pada tahun 2019. Model tipe ini juga melibatkan siswa dalam kegiatan pembelajaran, sehingga keaktifan siswa dapat meningkat (Qonita, 2017: 5). Prestasi belajar tiap siswa di diskusikan dan di pecahkan bersama sama satu kelompok, dan seluruh anggota kelompok bertanggung jawab atas hasil diskusi.Model belajar ini mengelompokkan siswadalam skala kecil (4-5 siswa) secara acakyang akan dipimpin ketua kelompok yang dianggap mampu 
memimpin teman temannya yang lain. Guru dapat fleksibel untuk memantau dari setiap kelompok ataupun siswa, kemudian para siswa dapat saling mengkoreksi atau mencocokkan hasil jawaban atas diskusi mereka, guru mulai mengidentifikasi permasalahan yang ada dalam kelompok yang bisa dibantu dan yang bisa diselesaikan sendiri oleh siswa.Setiap kelompok terdiri dari 5 siswa dan yang bertugas menyelesaikan materi pembelajaran. Setiap kelompok diberikan tugas yang berbeda untuk di diskusi dan dikerjakan bersama anggota kelompoknya. Poin-poin dalam tugas dibagikan secara berurutan kepada setiap anggota (misalnya, untuk materi Ilmu Pengetahuan Sosial yang memuat 8 soal, berarti empat anggota dalam setiap kelompok harus saling bergantian menjawab soal-soal tersebut). Semua anggota berganti mengkoreksi hasil jawaban teman dalam kelompoknya dan saling membantu jika memang diperlukan. Setiap kelompok harus memastikan bahwa semua anggotanya paham dengan materi yang telah didiskusikan.

Setiap anggota diberi tes mandiri tanpa bantuan dari anggota lain. Guru memperhatikan siswa saat menjalani tes individu. Perolehan skor dinilai dari kemampuan siswa bekerja sama, bekerja secara mandiri atau tidak menyontek hasil pekerjaan teman.Penghargaan (reward) kelompok akan diberikan pada kelompok yang mampu menjawab soal dengan benar dan mengerjakan tugas sesuai tegat waktu yang diberikan. Siswa yang mendapat nilai rata rata melampau KKM akan mendapat point tambahan guru karena dalam model Tipe Team Assisted Individualization siswa harus saling bekerja sama mengkoreksi dan mengerjakan tugas dengan siswa yang lainnya sehingga terjadi interaksi dalam kelompok, kemudian guru dapat memberi penjelasan materi materi yang dianggap terlalu sulit oleh siswa. Pada model Tipe Team Assisted Individualization ini, guru harus lebih menekankan unsur unsur akuntabilitas individu, kesempatan yang rata untuk sukses, dan dinamika motivasional. Model Tipe Team Assisted Individualization, siswa dituntut untuk saling beriteraksi dengan anggota kelompoknya. Keberhasilan masing masing siswa sangat ditentukan oleh keberhasilan kelompoknya. Menurut Sugiyono (2010: 101) Karakteristik model Team Assisted Individualization meliputi: (1) Kelompok dibentuk memuat 4 s.d 5 anggota yang berbeda beda kemampuan. (2) Pelaksanaan pretest atau tes awal untuk melihat tingkat kemampuan siswa dalam memahami konsep (3) Student Creativemelaksanakan tugas dalam suatu kelompok dengan menciptakan dimana keberhasilan individu ditentukan oleh keberhasilan kelompok. (4) Team Studyfase tindakan belajar yang harus dilakukan kelompok dan guru membantu secara individual kepada siswa yang kesulitan. (5) Team Score and Team Recognitionmengenai pemberian score terhadap hasil diskusi dan memberikan penghargaan pada kelompok yang telah berhasil dan kelompok yang dirasa kurang dalam menyelesaikan tugas. (6) Teaching Groupmerupakan pemberian materi singkat oleh guru sebelum pemberian tugas kelompok. (7) Fact Test, pelaksanaan tes kecil berpedoman fakta yang diperoleh siswa. (8) Whole-Class Units, guru memberikan materi kembali diakhir pembelajaran melalui strategi pemecahan masalah.

Proses pembelajaran menggunakan model Team Assisted Individualization perlu ditekankan kepada siswa bahwa keberhasilan pembelajaran masing maisng siswa menentukan keberhasilan kelompoknya, sehingga ada pelaksanaan pembelajaran ini siswa diharap mampu bekerjasama dengan anggota kelompoknya. Pada pelaksanaannya model Tipe Team Assisted Individualization meringankan guru dalam memberikan materi. Guru dapat sambil memberikan materi kepada siswanya. Menurut Sugiyono (2010: 120) Langkah langkah model Team Assisted Individualization yaitu: (1) Pemberian tugas ke siswa oleh guru untuk memahami materi secara mandiri; (2) Siswa mengerjakan tes awal untuk mengidentifikasi kemampuan awal siswa; (3) Pembentukkan kelompok, setiap 
kelompok memiliki kemampuan yang berbeda yang diperoleh pada hasil tes kemampuan awal, dari nilai tinggi, nilai sedang dan rendah, setiap kelompok memuat 4 s.d 5 anggota. (4) Siswa mendiskusikan bersama kelompoknya mengenai prestasi masing masing. Saat berdiskusi mereka saling bertukar jawaban antar anggota kelompok; (5) Guru memfasilitasi siswa dalam memahami materi (6) Siswa mengerjakan tes akhir secara mandiri; Siswa yang memperoleh nilai tertinggi akan memperoleh penghargaan dari guru. Hasil temuan penelitian yang dilakukan Iin Khairunnisa, Sugiharsono. (2015) bahwa model pembelajaran tipe Team Assisted Individualization efektif untuk meningkatkan minat belajar IPS.

Berdasarkan uraian latar belakang tersebut dapat diidentifikasi beberapa permasalahan yang terjadi di kelas IV SD Negeri Bendosari 03 Kecamatan Bendosari Kabupaten Sukoharjo Semester 2 Tahun Pelajaran 2018/2019 yaitu: Siswa terlihat pasif dan tidak aktif selama kegiatan belajar; nilai ulangan harian dari 8 siswa, yang tuntas dan dapat mencapai nilai kriteria ketuntasan minimal (KKM) yaitu 70 hanya 4 siswa atau 50\% dengan nilai rata-ratanya adalah 66.. Agar tidak meluas dan terfokus mendalam maka perlu adnaya pembatasan masalah yaitu Prestasi belajar IPS dalam hal ini pada materi aktivitas ekonomi masih perlu ditingkatkan agar mencapai kriteria ketuntasan minimal. Siswa Kelas IV SD Negeri Bendosari 03, Kecamatan Bendosari, Kabupaten Sukoharjo, Semester 2 Tahun Pelajaran 2018/2019 yang berjumlah 8 siswa. Dari pembatasan masalah di atas maka dapat dirumuskan permasalahan sebagai berikut. Apakah pemakaian model Team AssistedIndividualization dan berapa persentase prestasi belajar IPS materi aktivitas ekonomi siswa Kelas IV SDN Bendosari 03, Kecamatan Bendosari, Kabupaten Sukoharjo, Semester 2 Tahun Pelajaran 2018/2019 dan dapat meningkatkan prestasi belajar IPS siswa Kelas IV SDN Bendosari 03, Kecamatan Bendosari, Kabupaten Sukoharjo, Semester 2, Tahun Pelajaran 2018/2019. Tujuan penelitian ini yakni: Meningkatkan prestasi belajarIPS, mengetahui seberapa persen peningkatan pembelajaran IPS dan mengetahui penggunaan model Team AssistedIndividualization(TAI)mampu meningkatkan prestasi belajarIPS materi aktivitas ekonomi kelas IVSDN Bendosari 03, Kecamatan Bendosari, Kabupaten Sukoharjo, Semester 2, Tahun Pelajaran 2018/2019.

\section{Metode Penelitian}

Pelaksanaan Tindakan Kelas ini dilakukan di SDN Bendosari 03 Kecamatan Bendosari Kabupaten Sukoharjo pada siswa kelas IV semester 2, Tahun Pelajaran 2018/2019. Alasan pemilihan adalah karena penulis merupakan salah satu pengajar di sekolah tersebut sehingga memudahkan dalam pengambilan sampel serta pelaksanaan tindakan. Waktu penelitian selama 5 bulan yaitu dari Januari 2019 sampai dengan Mei 2019. Kegiatan tersebut dibagi dalam tahapan yaitu tahap ijin penelitian, tahap pelaksanaan dan tahap penyusunan laporan hasil penelitian. Jadwal pelaksanaan penelitian ini adalah Siklus I Pertemuan 1 pada tanggal, 6 Maret 2019, Siklus I Pertemuan 2 tanggal 13 Maret 2019 dan Siklus II Pertemuan 1 pada tanggal, 3 April 2019 sedangkan Siklus II Pertemuan 2 dilaksanakan tanggal, 10 April 2019. Subjek penelitian adalah seluruh siswa kelas IV Sekolah SDN Bendosari 03 Kecamatan Bendosari Kabupaten Sukoharjo yang berjumlah 8 siswa. Objek penelitian ini adalah prestasi belajar IPS Materi Aktivitas Ekonomi Siswa Kelas IV Sekolah SD Negeri Bendosari 03 Kecamatan Bendosari Kabupaten Sukoharjo. Data penelitian berupa hasil tes siswa dari kondisi awal, siklus I dan siklus II. Data observasi berupa hasil observasi kegiatan pembelajaran dengan menerapkanmodel tipe Team Assisted Individualization (TAI)pada muatan pelajaran IPS materi aktivitas ekonomi. Sumber data dari seluruh siswa Kelas IV SDN Bendosari 03 Kecamatan Bendosari Kabupaten Sukoharjo beserta guru kelasnya, selain itu juga dokumen yang berupa; daftar 
kelas tentang nama siswa dan jenis kelamin, RPP dan dokumentasi tentang kegiatan pembelajaran IPS Materi Aktivitas Ekonomi. Teknik pengumpulan data penelitian menggunakan 3 teknik yaitu (1) Dokumen adalah pengumpulan, penilaian, pengolahan dan penyimpanan informasi dalam bidang pengetahuan atau pengumpulan buktidan keterangan dalam penyelidikan. Manfaat dari dokumentasi adalah: untuk mencari data mengenai halhal atau variabel yang berupa catatan,transkrip,buku,surat kabar,majalah, prasasti,notulen rapat rutin dan sebagainya. (2) Teknik tes, yaitu adalah seperangkat soal, pertanyaan atau pun latihan untuk mengetahui kemampuan, intelektual, dan kemampuan bakat yang dimiliki individu atau kelompok. Manfaat tes adalah untuk mengukur kemampuan dasar dan pencapaian hasil atau prestasi belajar. (3) Teknik observasi difokuskan pada guru, siswa, dan objek lainnya yang dirasa perlu dalam pembelajaran secara aktual. Kegiatan observasi dilaksanakan pada saat berlangsungnya pembelajaran IPS materi aktivitas ekonomi melalui model Team Assisted Individualization. Validasi data yang diterapkan adalah triangulasi. Triangulasi ada empat macam, yaitu; metode, teori, sumber data dan antarpeneliti jikanpenelitian ini dilakukan berkelompok, pada penelitian ini hanya menggunakan dua triangulasi yaitu triangulasi metode; metode tes, observasi dan dokumentasi. Triangulasi yang kedua yaitu triangulasi sumber data dariguru kelas, siswa, dan dokumen.Teknik yang diterapkan dalam menganalisis data yaitu datayang didapat dari hasil observasi, tindakan dan dokumentasi. Kegiatan analisis merupakan refleksi dari data sebelum tindakan dan hasil selama dan setelah tindakan. Analisis data yang dinyatakan dalam bentuk deskripsi, yaitu hasil dari penelitian dianalisis kemudian disajikan dalam bentuk deskripsi sederhana.Perolehan prestasi belajar siswa dikatakan berhasil apabila persentase tuntas belajar secara klasikal $\geq 80 \%$ siswa kelas IV mendapat nilai $\geq$ KKMsekolah yang telah ditetapkan yaitu 70. Desain penelitian ini merupakan penelitian tindakan kelas yang dilaksanakan dalam dua siklus dan tiap-tiap siklus berisi empat tahapan, yaitu perencanaan, pelaksanaan tindakan, pengamatan dan refleksi. Kegiatan perencanaan tindakan meliputi tahapan berikut ini (a) membuat lembar observasi untuk melihat suasana pembelajaran, (b) mempersiapkanmetode yang akan digunakan yaitu modelTeam Assited Individualization (TAI), (c) membicarakan prosedur pelaksanaan pengajaran IPS materi aktivitas ekonomi dan (d) menyusun instrumen-instrumen yang akan digunakan. Kegiatan pelaksanaan dilaksanakan dalam 2 siklus, setiap siklus akan ada 2 kali pertemuan. Jika dari akhir pelaksanaan siklus keberhasilan belum sesuai dengan indikator yang diinginkan, maka akan diulang pada siklus berikutnya. Kegiatan observasi, terdiri dari guru mengamati keberlangsungan pembelajaran sertamencatat peristiwa selama proses pembelajaran terjadi. Refleksi tindakan, yaitu langkah untuk menganalisis semua kegiatan yang dilakukan dari siklus ke siklus, pada tahap ini penulis mencoba menganalisis terhadap proses pelaksanaan perbaikan pembelajaran di setiap siklusnya dan prestasi belajar berupa nilai ysng didapat dari tes evaluasi siswa pada setiap siklusnya, kemudian penulis merefleksikan hasil analisis tersebut untuk perbaikan pelaksanaan tindakan pada siklus berikutnya

\section{Hasil Penelitian}

Hipotesis tindakan menyatakan bahwa Model Team Assisted Individualizationyang diduga mampu meningkatkan prestasi belajarIPS materi aktivitas ekonomi siswa kelas IV Semester 2, SDN Bendosari 03 Kecamatan Bendosari Kabupaten Sukoharjo tahun pelajaran 2018/2019 telah teruji kebenarannya. Dapat dibuktikan dengan rata-rata IPS dan tingkat keberhasilan siswa yang meningkat dari siklus ke siklus.Kondisi awal, prestasi IPS siswa masih sangatlah rendah, dengan rata-rata siswa yang sebesar 66 dan tingkat keberhasilan siswa hanya sebesar $50 \%$. Kondisi tersebut diindikasikankarena siswa tidak 
terlibat secara langsung dalam keberlangsungan pembelajaran. Pembelajaran cenderung bersifat teacher-centered dan didominasi guru.Guna mengatasi hal tersebut maka guru berupaya melakukan perbaikan pembelajaran dengan mengaplikasikan model tipe Team Assisted Individualization. Pembelajaran model inimerupakan pembelajaran yang menuntun siswa mengkontruksi pengetahuan mereka melalui proses mencari dan menemukan. Penggunaan model ini diharapkan dapat merangsang siswa membangun konsep atau pengetahuan mereka sendiri. Nilai rerata siswa pada akhir tindakan Siklus I. adalah 74, nilai rata-rata yang diperoleh telah mencapai KKM yang ditetapkan dengan $\mathrm{KKM} \geq 70$ maka secara klasikal siswa dapat dikatakan telah mencapai ketuntasan belajar. Meskipun demikian, indikator penguasaan penuh secara klasikal berupa jumlah siswa yang telah tuntas belajar dengan $\mathrm{KKM} \geq 70$ sebanyak $\geq 80 \%$ belum tercapai, yaitu baru mencapai 75\% atau baru 6 siswa yang tuntas sedangkan 2 siswa $(25 \%)$ siswa belum tuntas. Hasil tes menunjukkan bahwa nilai terendah yang diperoleh siswa adalah sebesar 50, perolehan nilai tertinggi sebesar 90, dan nilai rerata sebesar 74. Mengingat perolehan rata rata $\geq$ KKM sebesar 70.00, maka dinyatakan siswa kelas IV SDN Bendosari 03 secara klasikal dapat dikatakan sudah mencapai ketuntasan belajar.Ditinjau dari ketuntasan belajar, hasil postest tindakan SiklusI menunjukkan bahwa 75\% atau 6 siswa sudah memperoleh nilai $\geq$ KKM, sisanya sejumlah 2 orang siswa (25\%) masih belum mencapai ketuntasan. Perolehan rata-rata siswa di siklus II, yaitu sebesar 85. Keberhasilan ketuntasan siklus II sebesar $100 \%$. Data hasil tindakan evaluasi siklus II terlihat bahwa siswa sudah mencapai ketuntasan, ketuntasan sudah maksimal yaitu mencapai $100 \%$, yaitu 8 siswa tuntas. Nilai rerata kelas sebesar 85 . Nilai terendah 80 dan nilai tertinggi 100. Perolehan rata rata juga sudah melampaui $\mathrm{KKM}$ yang ditetapkan dengan $\mathrm{KKM} \geq 70$, maka siswa kelas IV SD Negeri Bendosari 03 secara klasikal sudah berhasil mencapai ketuntasan.

Tabel 1.Skor Ulangan Harian Setiap Siklus

\begin{tabular}{llccc}
\hline No & Uraian & Kondisi Awal & Siklus I & Siklus II \\
\hline 1 & Nilai Tertinggi & 80 & 100 & 100 \\
\hline 2 & Nilai Terendah & 40 & 60 & 80 \\
\hline 3 & Nilai rata-rata & 66 & 74 & 85 \\
\hline 4 & Tuntas & 4 & 6 & 8 \\
\hline 5 & Tidak tuntas & 4 & 2 & 0
\end{tabular}

Tabel 2.Ketuntasan Siswa Setiap Siklus

\begin{tabular}{lcccc}
\hline \multirow{2}{*}{ Tahapan Siklus } & \multicolumn{2}{c}{ Ketuntasan Siswa } & \multicolumn{2}{c}{ Prosentase Ketuntasan } \\
\cline { 2 - 5 } & Tuntas & Belum Tuntas & Tuntas & Belum Tuntas \\
\hline Kondisi awal & 4 & 4 & $50 \%$ & $50 \%$ \\
\hline Siklus I & 6 & 2 & $75 \%$ & $25 \%$ \\
\hline Siklus II & 8 & 0 & $100 \%$ & $0 \%$ \\
\hline
\end{tabular}

Berdasarkan data yang telah diperoleh maka model tipe Team Assisted Individualizationdiduga dapat meningkatkan prestasi belajar IPS materi aktivitas ekonomi Siswa Kelas IV semester 2 SDN Bendosari 03 Kecamatan Bendosari Kabupaten Sukoharjo tahun pelajaran 2018/2019teruji kebenarannya.

\section{Pembahasan}

Berdasarkan data yang diperoleh dari sekolah, keadaan siswa SD Negeri Bendosari 03, khususnya di kelas IV, pelajaran IPS materi Aktivitas Ekonomi. Guru dan siswabelum menerapkan model pembelajaran yang sesuai dan menarik, sehingga siswa hanya 
mengamati dan menyimak materi yang dijelaskan oleh guru, dilanjutkan tugas mandiri. Sehingga membuat siswa merasa jenuh dan tidak menarik untuk mengikuti pembelajaran, Dalam kegitan orientasi dan identifikasi masalah terlebih dahulu dilakukan tes untuk mengukur kemampuan siswa (tes awal) tentang materi aktivitas ekonomi.Hasil tes diperoleh dari nilai ulangan harian yang diperoleh dari 8 orang siswa dapat diketahui bahwa nilai terendah yang diperoleh adalah sebesar 50, nilai tertinggi sebesar 80 , dan nilai ratarata kelas diperoleh sebesar 66. Perolehan rata-rata sebesar $66<\mathrm{KKM}$ sekolah, yaitu sebesar 70,00. Atas dasar hal tersebut, maka siswa kelas IV SD Negeri Bendosari 03 Kecamatan Bendosari Sukoharjo tahun pelajaran 2018/2019 secara klasikal belum mencapai ketuntasan belajar IPS materi aktivitas ekonomi. Merujuk pada tingkat ketuntasan belajar, dari 8 siswa yang ada, siswa yang mendapatkan nilai $\geq$ KKM baru mencapai 4 siswa (50\%). Sisanya sebanyak 4 siswa (50\%) belum mencapai batas tuntas, maka secara klasikal siswa belum mencapai batas tuntas keberhasilanyang dipersyaratkan $\geq$ 80.00\%.Pada siklus Ipenulis menerapkan penggunaan model Team Assisted Individualization, diperoleh rata-rata kelas pada siklus pertamaadalah 74, sudah mencapai nilai KKM yang telah ditentukan. Nilai tertinggi siswa adalah 90 dan nilai terendah adalah 50. Siswa yang mencapai nilai KKM sebanyak 6 siswa $(75 \%)$, belum mencapai indikator keberhasilan. Peningkatan hasil belajar IPSMateri Aktiivtas Ekonomi di kelas IV pada siklus pertama ini belum mencapai indikator keberhasilan sehingga penulis melanjutkan ke siklus selanjutnya. Berdasarkan hasil evaluasi tindakan pembelajaran pada Siklus I dapat diperoleh refleksi hasilpembelajaran IPS dengan menggunakan model tipe Team Assisted Individualizationsebagai berikut: (1) Implementasi modelTeam Assisted Individualization (TAI)pada tindakan Siklus I mampu meningkatkan implikasi produk pembelajaran berupa meningkatnya prestasi belajar IPS. Terbukti dengan meningkatnya rerata kelas yang diperoleh siswa, maupun tingkat ketuntasan keberhasilan belajar siswa. Perolehan rata-rata kelas sebagai dampak produk pembelajaran di awal hanya sebesar 66,di siklus pertamasebesar74terjadi peningkatan meskipun belum maksimal. Ketuntasan keberhasilan belajar sebagai dampak produk juga mengalami peningkatan, di awal hanya mencapai 50\% sebelum adanya tindakan, setelah diberi tindakan meningkat menjadi $75 \%$ di siklus I (2).Hal-hal yang masih belum berhasil dalam pembelajaran tindakan Siklus I adalah: Perlu diubah pola pembelajaran dimana guru tidak lagi menjadi pusat pembelajaran, tetapi siswa lah yang menajdi pusat pembejalaran; keahlian siswa dalam mengkontruksi pengetahuan yang masih rendah;Aktivitas guru dalam dengan pendekatan proses masih belum maksimal, yaitu baru mencapai tingkatan cukup baikdan ketuntasan kelas secara klasikal dengan perolehan rata-rata kelas $\geq 74$ serta dampak produk berupa penguasaan kompetensi menyeluruh $\geq 80.00 \%$ belum tercapai.

Pelaksanaan siklus II, mengingat perolehan rata-rata kelas yang diperoleh sudah melampaui $\mathrm{KKM}$ yang ditetapkan dengan $\mathrm{KKM} \geq 70$, maka siswa kelas IV SD Negeri Bendosari 03,Kecamatan Bendosari secara klasikal sudah mencapai ketuntasan belajar. Ditinjau dari penguasaan penuh secara klasikal, terdapat 8 orang siswa atau $100 \%$ siswa yang sudah mencapai ketuntasan keberhasilan KKM $\geq 70$ adalah sebanyak 8 orang siswa atau $100 \%$. Refleksi dilaksanakan satu minggu setelah pertemuan ke-2 siklus II, setelah pelaksanan tes evaluasi. Hasil tes yang dieproleh membuktikan adamya pengaruh yang positif dalam hal tingkat keberhasilan ketuntasan. Refleksi dari hasil evaluasi siklus II menggunakan model Team Assisted Individualization dalam pembelajaran IPS konsep "Aktivitas Ekonomi" yaitu (1) Penggunaan model pembelajaran dengan model tipe Team Assisted Individualization terbukti berhasil meningkatkan dampak produk berupa 
meningkatnya prestasi belajar IPS siswa. Perolehan nilai rerata siswa mengalami dari kondisi awal sebelum tindakan yaitu 66, setelah diadakan tindakan menjadi 74 pada siklus I, menjadi 85 pada akhir Siklus II,dari perolehan rata rata tersebut dapat terbukti bahwa ada peningkatan di setiap siklusnya. Ketuntasan keberhasilan siswa sebagai hasil produk juga mengalami peningkatan, yaitu dari kondisi awal sebelum diterapkannya model pembelajaran hanya $50 \%$, setelah mendapat tindakan menerapkan model pembelajaran menjadi $75 \%$, dan meningkat menjadi $100,00 \%$ di akhir siklus. (2) aspek yang masih belum berhasil dalam pembelajaran siklus I sudah dapat tercapai pada siklus II. Hal tersebut adalah: (a) Pemahaman materi secara klasikal sebesar $\geq 80.0 \%$, yang tadinya belum terpenuhidi akhir siklus II dapat terpenuhi; dan (b) pemahaman siswa dalam menyusun konsep sudah menunjukkan kemajuan. Sejalan dengan penelitian yang dilakukan oleh I Gusti Ayu Kencana (2014) yang membuktikan bahwa model pembelajaran TAI berbasis peta konsep berpengaruh terhadap hasil belajar siswa kelas 5 SD Gugus Sukawati, Gianyar tahun 2013/2014. Hal ini juga sejalan dengan hasil penelitian Aliffah Fajarwati tahun 2017 yang menerapkan model Team Assisted Individualization dalam pembelajaran pengurangan dan penjumlahan pecahan. Pada penelitiannya terbukti bahwa model tersebut mampu meningkatkan kualitas proses pembelajaran. Penelitian yang relevan dengan penelitian ini juga pernah dilakukan I Dewa Ayu Putu Suryatitahun 2019 yang penerapan menerapkan model Team Assisted Individualization dapat meningkatkan prestasi belajar siswa. I dewa Ayu juga berpendapat bahwa model tersebut cocok untuk melatih siswa berkreasi, berargumentasi dan mengeluarkan pendapat. Penelitian lain yang serupa juga dilakukan oleh Suparti tahun 2018 yang menghasilkan peningkatan hasil belajar dan menciptakan Susana yang kondusif dan keterlibatan siswa secara langsung dengan diterapkannya model Team Assisted Individualization. Maman Achdiyat dan Fitriya Andriyani tahun 2016 membuktikan bahwa siswa menjadi lebih aktif dalam mengerjakan soal dan model ini dapat mengembangkan motoric siswa. Berdasarkan paparan di atas menyatakan bahwa model TAI dapat meningkatkan dan menjadikan siswa lebih berperan aktif dalam pembelajaran.

\section{Simpulan dan Saran}

Berdasarkan data analisis dan pembahasan maka dapat disimpulkan bahwa: "Penggunaan Model Team Assisted Individualization terbukti dapat meningkatkan prestasi belajar IPS Materi Aktivitas Ekonomi siswa Siswa Kelas IV SD Negeri Bendosari 03, Kecamatan Bendosari, Kabupaten Sukoharjo, Semester 2 Tahun Pelajaran 2018/2019”.Hal ini dibuktikan dengan peningkatan prestasi belajar dari keadaan awal hingga siklus II, yaitu

Persentase ketuntasan belajar secara klasikal pada kondisi awal50\%, menjadi 100\%, memasuki akhir siklus II, terbuktiada peningkatan sebesar 50\%. Peningkatan lain juga meliputi: (a) Pemahaman materi secara klasikal sebesar $\geq 80.0 \%$, yang tadinya belum terpenuhidi akhir siklus II dapat terpenuhi; dan (b) pemahaman siswa dalam menyusun konsep sudah menunjukkan kemajuan. Upaya peningkatan prestasi belajar IPS siswa dapat dilakukan setiap kepala sekolah dengan berperan aktif dalam mendukung penerapan model model pembelajaran yang berkembang saat ini baik, terutama yang berhubungan dengan mata pelajaran Ilmu Pengetahuan Sosial, karena dapat meningkatkan motivasi belajar siswa, sehingga siswa lebih semangat dalam belajar. Bagi guru kelas, guru kelas lainnya disarankan dapat menerapkan model pembelajaranTeam Assisted Individualization dalam proses pembelajaran. Dampak pembelajaran ini bagi siswa adalah dapat merangsang siswa untuk berpasrtisipasi aktif mengkonstruksikan pengetahuan mereka. Guru kelas disarankan agar dapat mengkondisikan kelas sehingga proses pembelajaran dapat berlangsung secara optimal. Guru kelas disarankan untuk berinteraksi dan berkomunikasi yang baik dengan 
siswa karena hal itu akan menciptakan suasana pembelajaran yang komunikatif dan menyenangkan. Bagi siswa, lebih ditingkatkanketertiban dan fokus dalam mengikuti jalannya pembelajaran di kelas. Siswa disarankan berperan aktif pada proses pembelajaran melalui penerapan model tipe Team Assisted Individualization dalam pembelajaran IPS.

\section{Daftar Rujukan}

Aat Haryati. (2017). Penggunaan Model Team Assisted Individualization untuk Meningkatkan Hasil Belajar Peserta Didik. Jurnal Penelitian Pendidikan Islam, volume 4(1), hal: 47-60. https://riset-iaid.net/index.php/jppi/article/view/15

Aliffah Fajarwati. (2017). Implementasi Model Pembelajaraan Kooperatif Tipe TeamAssisted Individualization (TAI) untuk Meningkatkan Kemampuan Menghitung Penjumlahan dan Pengurangan pecahan pada Siswa Sekolah Dasar.Jurnal Pendidikan Indonesia, volume 5(3), hal: 1-5.

Asmara. (2009). Prestasi Belajar. Bandung: PT Rosdakarya.

Dimyati \& Mudjiono.(2002). Belajar dan Pembelajaran. Jakarta: Rineka Cipta.

Dina Qonita. (2017). Penerapan Model Pembelajaran Team Assisted Individualization untuk Meningkatkan Kemampuan Menghitung Bilangan Bulat pada Siswa Sekolah Dasar. Jurnal Pendidikan Indonesia, volume 4(2), hal: 189-194.

Harjati. (2008). Psikologi Belajar. Jakarta: PT Rineka Cipta.

Hetika. (2008). Pembelajaran Menurut Aliran Kognitif Edisi 2008. Jakarta: Rineka Cipta.

Iin Khairunnisa \&Sugiharsono. (2015). Keefektifan model pembelajaran kooperatif metode Problem Solving dan tipe Team-Assisted Individualization (TAI) dapat meningkatkan minat dan hasil belajar IPS. Harmoni Sosial: Jurnal Pendidikan IPS, volume 2(1), Maret 2015, hal: 12-20.

I Dewa Ayu Putu Suryati. (2019). Penerapan Pembelajaran Kooperatif Tipe Team Assisted Individualization (TAI) Untuk Meningkatkan Aktivitas dan Prestasi Belajar IPA pada Siswa Kelas VI SD Negeri 3 Penatih. J.Vidya Wertta Universitas Hindu Indonesia, volume 2(2), hal: 192-202. https://doi.org/10.32795/vw.v2i2.399.

I Gusti Agung Inten Prabaningrum dan I Ketut Adnyana Putra. (2019). Pengaruh Model Pembelajaran Kooperatif Team Assisted Individualization Berbantuan Media Semi Konkret Terhadap Kompetensi Pengetahuan Matematika. Jurnal Ilmiah Sekolah Dasar, volume 3(4), hal: 405-413.

I Gusti Ayu Kencana. (2014). Pengaruh Model Pembelajaran Kooperatif TAI Berbasis Peta Konsep Terhadap Hasil Belajar IPS Siswa Kelas V Gugus VIII Sukawati. Jurnal Mimbar PGSD UNDIIKSHA, volume 2(1), hal: 1-10.

Maman Achdiyat \& Fitriya Andriyani. (2016). Hasil Belajar Matematika Ditinjau dari Model Pembelajaran Teams Assisted Individualization (TAI). Jurnal Ilmiah Pendidikan MIPA UNINDRA, volume 6(3), hal: 246-255.

Ni Luh Sutiari. (2019). Penerapan Model Pembelajaran Kooperatif Tipe TAI(Team Assisted Individualization) untuk Meningkatkan Aktivitas dan Prestasi Belajar pada Matapelajaran Tata Graha. Jurnal Ilmiah Pendidikan dan Pembelajaran UNDIKHSA, volume 3(1), hal: 32-40.http://dx.doi.org/10.23887/jipp.v3i1.17107.

Slameto. (2003). Belajar dan Faktor Faktor yang Mempengaruhinya. Jakarta:Rineka Cipta.

SlavinRobert E. (2005). Cooperative Laerning. London: Allymand Bacon.

Sugiyono. (2010). Metode Penelitian Pendidikan Pendekatan Kuantitatif, Kualitatif dan $R \& D$. Bandung: Alfabeta. 